\title{
REPUTABLE TEACHER'S DEVELOPING LESSON PLAN AND ITS IMPLEMENTATION IN THE CLASSROOM
}

\author{
Muhammad Saifuddin, \\ Fakultas Bahasa dan Sastra, Universitas Pesantren Tinggi Darul 'Ulum \\ (UNIPDU) Jombang \\ ms_saif85@yahoo.co.id
}

\begin{abstract}
Abstraksi: Menciptakan proses belajar mengajar memerlukan perencanaan yang baik dan keterampilan mengajar guru. Sebagai seorang guru, mereka harus mampu melakukan proses pembelajaran secara efektif dan bermakna untuk membantu siswa mencapai tujuan pembelajaran. Selain itu, para guru dituntut untuk membuat rencana pelajaran dan menerapkannya., penelitian ini bertujuan untuk menggambarkan bagaimana guru mengembangkan rencana pelajaran dan menerapkannya dalam proses belajar mengajar. Metode studi kasus digunakan dalam penelitian ini untuk menggambarkan proses pembelajaran yang berdasarkan rencana pelajaran yang telah dikembangkan. Hasil penelitian menunjukkan bahwa rencana pelajaran dikembangkan guru terkemuka itu dilakukan dengan baik berdasarkan teori pengembangan rencana pembelajaran dan berdasarkan peraturan Kementerian Pendidikan. RPP menunjukkan kesalingterkaitan antara semua komponen RPP, mereka adalah; kompetensi dasar, kompetensi dasar sub, indikator, tujuan pembelajaran, kegiatan belajar mengajar, metode, strategi pembelajaran, media dan sumber, dan penilaian.
\end{abstract}

Kata kunci: guru terkemuka, rencana pelajaran

\section{A. INTRODUCTION}

The importance of teaching English as a foreign language is to have learners understand the knowledge delivered by the teacher. As a teacher, it is understandable that to teach is first to understand. It is because teaching is not only a matter or delivering materials to the students but rather understanding how the students can accept our teaching ways and also understand the materials given. Besides, teaching English requires the teacher's teaching skills and knowledge of English language. Widdowson (2002) state that teacher's knowledge of the 
language subject means the knowledge of the language, and how it can be managed to make it learnable, which in turn involves managing to induce to learn. The English teacher uses their knowledge to adopt their knowledge of language to be transferred in order to make it easier and applicable for the learners to learn. The knowledge of the English language also reflects on teachers' movement to persuade them enthusiastically learn the language.

Teachers' understanding on teaching is a conceptually sphere of influence for basic teaching skill. The teachers need to show to the students that what they understand to teach, what knowledge they need to transform, or what the values they enact for, these let the students who do not know will come to know, those who are not desire will come to desire to learn. Shulman (1986) states that teachers' transforming understanding, performing skills, desire attitude become ways of their showing, enacting, or representing ideas so that the unknowing will come to know, the unskilled will become adept. Therefore, among the teacher and the students, there must be a comprehension of the context. The teachers' understanding of what is to be learnt and how it is to be taught eases the students internalize a good comprehension.

Furthermore, related to enhancing teachers' ability in conducting teaching process, the regulation of National Education Ministry (Number 16 years 2007) states that the teachers must have standardized competences which are developed from four main competencies: namely pedagogical competence, social competence, personal competence, and professional competence. Those competencies are very essential for the teachers to master. It is because the 
teachers who are competent enable to fulfill both school and students' needs. It is the teachers' duty as the agent of education which takes an important part to the process of learning.

On the other hand, the teachers should create learning which is creative, inspiring, enjoyable, and also challenging in order to motivate students to maintain their creativity, physical development, and psychological development as they are given more opportunities in learning (Permendikas Number 19 years 2005). In fact, the teachers need to create students' understanding on the content taught. To do so, the teachers should give them assistance to bridge the students connect their understanding of the content toward their prior knowledge and experience. In this case, creating such classroom condition, the teacher must be able to design lesson plan. This lesson plan will meaningfully help the teacher conduct teaching and learning process. Besides, designing lesson plan is also covered in pedagogical competence which the teacher must possess. Pedagogical competence refers to teacher's mastery of the subject, skills in lesson planning, lesson presentation, and in evaluation (Calvin \& Chumba, 2011). On the other hand, teachers' planning is necessarily required to the process of learning. Planning is essential to guide the teachers teach; remind them on some activities which are required to do. Harmer (2007, p. 156) states that a lesson plan aims to help remind the teachers what they intended to do. The significance of planning is that it is expected to fulfill learners' needs. They refer to the ability of teacher to plan lesson, adapt and modify their delivery by taking account of how the lesson will be experienced by different learners and foster their learning. 
To be able to create a good process of learning, the teachers need to find classroom strategies. Furthermore, learning a language takes a process and it can be best built through the process of development. Good learning strategies chosen by the teachers as they are demanded to be able to understand students' way of learning shapes good classroom activities. Snow and Townsend in Valentino (2010) state that when learning another language, teacher-parent contacts, practices, structures, and enrichments are critically important during the early stages of learning process and are very important for classroom activities.

To meet teachers' abundant duty, teachers need not only to have passion in teaching but also to have competencies. The regulation of National Education Ministry (Number 19 years 2005) states that teachers as the agent of teaching and learning must have academic qualifications and competencies, good healthy both mental and physical and have the ability to maintain the goal of national education. The competencies which the teacher should have cover pedagogical competence, personal competence, social competence, and professional competence.

In teaching and learning activities, there is a relationship between the teacher and the students. The teachers should be able to transmit the knowledge and guide the learners to the goal while the learners (Pratt, 1989). In this case, the teachers must be able to bring them to the real world through the activities which experience them in learning. Teachers' individual experience and knowledge of teaching shape what they do and how they do teaching. On the other hand, in 
understanding the teaching roles, the teachers' knowledge may also shape their choice toward students' learning. It is supported by Loughran (2010), who states that teachers own personal perspective on the issue of teaching knowledge shapes not only what we do and how we do it but also the choice we make and why.

Competent teachers are expected to help learners learn effectively and successfully. Effective teaching involves effective teachers' who have teaching competence, especially teaching skills. Competence, therefore, is defined in terms of the mastery of basic teaching skills and procedures that have been shown to correlate with learners' achievement (Pratt, 1989). In addition, the English teachers need to have caliber and qualities appropriate for different level (Patel \& Jain, 2008). A good teacher of English must possess some qualities, they are:

1. Having sound of knowledge of English language as well as literature,

2. Knowing different methods of teaching English,

3. Having an ability and skill to teach methodically and systematically, and

4. Having an ability to understand his students.

Lesson plan is used to direct teaching and learning activities systematically in order to create learning interactively, enjoyable, challengeable, and motivate learners to be actively involved. A lesson plan is a written work plan for the teachers to be implemented for teaching and learning in a single class period (Hook \& Evans, 1982). In developing lesson plan, there is one important thing to be considered, that is the objectives of learning. Lesson plan plays a role in transforming school curriculum to classroom instruction in which it emphasizes on students to gain particular knowledge or skill (Shambaugh \& Magliaro, 2006). 
A unit of lesson plan has been made and used by most teachers in this universe. The teachers plan, organize, and design ahead the content which the teacher will be presenting. By doing so, the teachers take enormous steps toward owning the content they teach (Valentino, 2010).

Lesson plan is developed based upon one basic competence. Basic competence refers to a set of ability which learners must be able to master on a particular subject matter (Permendiknas Number 41 years 2007). In order to reach its function, there are some components need to fulfill in developing lesson plan as it is ordered by Ministry of National Education (Number 41 years 2007):

1. Subject identity

2. Standard of competence

3. Basic competence

4. Indicator

5. The Objective

6. Learning strategy

7. Time allocation

8. Approach/learning method

9. Teaching and learning activities

10. Assessment

11. Resources

Furthermore, it is essential to develop lesson plan systematically. What is meant by systematically is an orderly, regular, and uniform activity. Systematicity also provides interconnectivities of the activity phases, so that what we learn in one phase informs decisions to be made in the next phase (Shambaugh \& Magliaro, 2006).

In addition, preparation and planning are the important aspects to contribute to the success of the teaching process. A lesson plan should be flexible and applicable in the classroom teaching activities. The teachers may modify their 
lesson plan depending on their students; situation, they need to make certain activities to help and encourage students' passion in learning process.

Competent teachers understand that using lesson plan in teaching and learning process is really significant. It is because lesson plan helps them much in reminding them to what they really intended to do during learning activities (Harmer, 2007). It is their desire to plan the lesson to organize learning materials in order to lead the learners to achieve the goal or to gain a certain competence. As it is based on the regulation of Minister of National Education Number 41 years 2007 that in developing lesson plan, there are some components which should be fulfilled. Then, it is essential to understand the main steps in developing lesson plan (Sanjaya, 2008):

a. Formulate the specific goals

The first thing which the teacher should do is to formulate specific learning objectives with their materials. These specific objectives are formulated as an indicator of learning outcomes. Its function is as a technique to achieve general or standard learning objectives which are proposed by the curriculum. According to Sujinah (2011) who states that in formulating learning objectives, it should be based on standardized competence, basic competence, and indicators which determined previously.

b. Choose learning strategies

The teachers should create effective learning strategies as a result the learners can achieve the learning objectives or achieve the basic competence. Learning strategies involve the teachers to present the lesson, how the teachers 
organize the learning materials, and how the teachers appropriately select certain technique in presenting certain material.

c. Set teaching and learning activities

Teaching and learning activities consists of opening, main, and closing activities (Sujina, 2011, Permendiknas No. 41 years 2007).

1. Opening Activities

The opening activities function is to make the students prepare mentally and physically to follow the teaching activities process. It is supported by Usman (2004) who states that opening activities lead the learners to the precondition which indicates the learners are ready to focus their attention to what they are going to learn. In this section, the teachers can fill the activities such as checking students' attendance list, leading them to the materials which are going to be learned, motivating the students by showing such media of learning, stating the objectives of learning, telling them the activities which are going to do, etc.

\section{Main Activities}

The objective of main activities is to achieve basic competences. These activities should be meaningful, interactive, and challenging. In constructing main activities, it depends on indicators. The indicators have been formulated leads the teachers to organize the activities. The activities show the steps of what the students do from the lower level to upper level of difficulties. The well-organized activities guide the students to achieve the basic competence as it is shown on each indicator that is developed in the main learning activities. 


\section{Closing Activities}

Closing activities is the activity done by the teachers to end the whole learning activities. It is intended to give the students a picture of understanding to what they have been learned, and to identify learners achievement during teaching and learning process (Usman, 2004).

d. Determine teachers' role

Teachers' role is very significant in learning process. Teachers can be as a manager, facilitator, informant, or sources. In order to maintain teachers' role, the teachers must have good communication, good at using the media, and so forth.

e. Select sources and tools

Teaching materials are the key component in language teaching. It serve the basis of language input which the learners receive and practice in classroom (Richard, 2001, p. 251). Among the provided sources of the materials, the teachers are required to be able to select and use the source as it becomes learnable sources. He also notes that the teachers are provided with two different roles of materials used, they are authentic and created materials. Authentic material refer to the use in teaching text, photographs, video, brochure, advertisement or other sources which are not specifically prepared for pedagogical purposes. Meanwhile, created material refers to textbooks or others which are developed specially for instructional and pedagogical purpose. 


\section{f. Develop assessment/evaluation}

Assessment also takes important role in teaching in which its result gives description for the teacher to know the students' understanding and achievement. Assessment is an ongoing process that encompasses a much wider domain. In case, the students respond to questions, offer a comment, or try out a new word, the teacher subconsciously makes an assessment of the students' performance (Brown, 2004, p. 4).

Based on the rationales above, it is important to investigate how reputable teacher actually plans his or her lesson and how these plans are implemented in classrooms.

\section{METHODS}

As this study was intended to investigate the reputable English teacher's developed lesson plan and how the teacher implemented it in teaching and learning process, a case study was used in this research. The data were taken from observation and interview. The observation covered analysis of the teacher's lesson plan and the suitability of the lesson plan and its implementation. The analysis of the lesson plan was based on some indicators, they were; (1) Determining competences and indicators, (2) Materials development, (3) Learning strategies, (4) Teaching and learning activities, and (5) Evaluation. This analysis was intended to see the teacher's competence of developing lesson. Meanwhile, teacher's teaching process was observed as well to see the suitability of lesson plan and its implementation. On the other hand, as it was aimed to investigate 
teacher's competence, the interview was undergone to know teacher's way of developing lesson plan.

\section{FINDINGS AND DISCUSSIONS}

Based on the lesson plans had made, it covered all the recommended components which was proposed by the Ministry of National Education. The following table showed the proof of it.

Table 1. Components of Teacher's Developed Lesson Plan

\begin{tabular}{|l|l|c|}
\hline No. & Ideal Lesson Plan components & Class VIII \\
\hline 1. & Subject identity & $\sqrt{ }$ \\
\hline 2. & Standard of competence & $\sqrt{ }$ \\
\hline 3. & Basic competence & $\sqrt{ }$ \\
\hline 4. & Sub-basic competence & $\sqrt{ }$ \\
\hline 5. & Indicators & $\sqrt{ }$ \\
\hline 6. & Learning Objective & $\sqrt{ }$ \\
\hline 7. & Learning strategy & $\sqrt{ }$ \\
\hline 8. & Time allocation & $\sqrt{ }$ \\
\hline 9. & Approach/learning method & $\sqrt{ }$ \\
\hline 10. & Teaching and learning activities & $\sqrt{ }$ \\
\hline 11. & Assessment & \\
\hline 12. & Resources & \\
\hline
\end{tabular}

Related to table 4.1, it showed that the lesson plan fulfilled the ideal lesson plan components. From these all about, in detail, the stated basic competence was the core of the lesson plan. Among indicators, learning strategy, teaching and learning activities, as well as assessment, they should accommodate the basic competence. It definitely became the main goal of the teaching learning process. As it was known that basic competence must be set up based on standard of competence, the teacher formulated one competence which based on standard of competence by breaking down the basic competences into single contained competence. 


\section{A. STANDARD OF COMPETENCY}

6. To express the meanings in written short functional texts and essays in the form of descriptive, recount, and exposition texts for communicating with the surrounding environment and in the academic context.

B. BASIC COMPETENCE

6.2 To express the meanings in short essays in the form of descriptive, recount, and exposition texts accurately, orderly and acceptably for communicating with the surrounding environment and in the academic context.

\section{SUB BASIC COMPETENCE}

6.2.1 To express the meaning in short essays in the form of descriptive accurately, orderly and acceptably for communicating with the surrounding environment and in the academic context.

This chronological order of formulating basic competence proved the appropriate way done by the teacher. Thus, the students should achieve one competence in a single teaching and learning process. It sustained the teacher to organize the actions of teaching procedures to achieve it. Furthermore, this formulated basic competence was used to determine the indicators of learning. The indicators shaped the stages of learning activities. The indicators should reflect Bloom's Taxonomy (Morrison, Ross, \& Kemp, 2007) which require the students to achieve the basic things before achieving the next level.

Table 2. Indicators' Classification

\begin{tabular}{|c|c|c|}
\hline Bloom Taxonomy & $\begin{array}{l}\text { Indicators of Achievement } \\
\text { (On the Lesson Plan) }\end{array}$ & Key Word (Verb) \\
\hline Knowledge & $\begin{array}{l}\text { 1. Identify the } \\
\text { structure of } \\
\text { descriptive text }\end{array}$ & Identify \\
\hline Comprehension & $\begin{array}{l}\text { 2. Classify the } \\
\text { sentences }\end{array}$ & Classify \\
\hline Application & 3. Write sentences & Write \\
\hline Analysis & 4. Select the sentences & Select \\
\hline
\end{tabular}




\begin{tabular}{|c|c|c|c|}
\hline & & $\begin{array}{l}\text { based on the structure } \\
\text { of descriptive text }\end{array}$ & \\
\hline Synthesis & & $\begin{array}{l}\text { Arrange the } \\
\text { jumble sentences } \\
\text { Compose a short } \\
\text { descriptive text }\end{array}$ & $\begin{array}{l}\text { Arrange } \\
\text { Compose }\end{array}$ \\
\hline Evaluation & & $\begin{array}{l}\text { Compare their } \\
\text { descriptive text } \\
\text { by valuing the } \\
\text { content of the text }\end{array}$ & Compare \\
\hline
\end{tabular}

These indicators fulfilled the requirement of learning stages by using Bloom's taxonomy. Indeed, these indicators were used to determine the learning objectives. Based on this lesson plan, the learning objectives indicated that the teacher wanted to lead the students to reach the basic competence by achieving each indicator orderly so that the students attained different level of learning objectives.

The important part of lesson plan was stating the learning objectives which became the mainstream of setting teaching and learning activities. Looking at the standard of competence, the formulation of basic competence, indicators, and learning objectives, the teacher was purposively able to arrange the goal of the learning and the students' learning stages. This teacher's ability was supported by Sujinah (2011) who states that in formulating learning objectives, it should be based on standardized competence, basic competence, and indicators which determined previously.

Meanwhile, to strengthen the learning objectives, the teaching and learning activities should be developed based on the indicators. The lesson plan showed teaching and learning activities in three parts; opening, main, and closing 
activities. For each part, it was proved that all the activities were managed orderly and accordingly.

In opening part, the lesson plan had used the components of how to begin the lesson. The activities covered leading the students to material, motivating the students, and stating the learning objective. These activities were appropriately arranged as they were the ideas of how to prepare the students mentally and physically (Usman, 2004). Moreover, the implementation of the lesson plan, the teacher did what were written in the lesson plan which included telling and describing the learning objectives that the students should achieve at the end of the lesson.

On the other hand, the main activities should also be able to accommodate the basic competence as it was intended to attain the expected learning outcomes.

Table 3. Agreement between Indicators and Teaching and Learning Activities

\begin{tabular}{|c|c|}
\hline Indicators & Teaching and Learning Activities \\
\hline $\begin{array}{l}\text { 1. Identify the structure } \\
\text { of descriptive text }\end{array}$ & $\begin{array}{l}\text { 1) Teacher asks the students to identify the } \\
\text { structure of descriptive text. }\end{array}$ \\
\hline 2. Classify the sentences & $\begin{array}{l}\text { 2) Teacher asks the students to make a group } \\
\text { 3) Students make some groups that each group } \\
\text { consists of three students. } \\
\text { 4) Teacher gives an envelope which consists of a } \\
\text { descriptive text } \\
\text { 5) Teacher asks the students to classify the } \\
\text { paragraphs based on the structure of } \\
\text { descriptive text }\end{array}$ \\
\hline 3. Write sentences & $\begin{array}{l}\text { 6) Teacher distributes an envelope which consists } \\
\text { of pictures of actors and actress and asks each } \\
\text { group to write sentences based on the picture. }\end{array}$ \\
\hline $\begin{array}{l}\text { 4. Select the sentences } \\
\text { based on the structure } \\
\text { of descriptive text }\end{array}$ & $\begin{array}{l}\text { A) Ask the students to select their sentences based } \\
\text { on the structure of descriptive text. }\end{array}$ \\
\hline
\end{tabular}




\begin{tabular}{|c|c|}
\hline $\begin{array}{l}\text { 5. Arrange the } \\
\text { jumble sentences }\end{array}$ & $\begin{array}{l}\text { 8) Teacher distributes some envelopes again. } \\
\text { 9) Teacher asks the students to arrange the } \\
\text { jumbled sentences into a good paragraph. } \\
\text { 10) Teacher asks the groups to match the pictures } \\
\text { and the paragraphs. }\end{array}$ \\
\hline $\begin{array}{l}\text { 6. Compose a short } \\
\text { descriptive text }\end{array}$ & $\begin{array}{l}\text { 11) Teacher and students discuss more about the } \\
\text { descriptive text and the way how to compose a } \\
\text { good descriptive text. } \\
\text { 12) Teacher gives the students a picture of a } \\
\text { famous boy and asks them to compose a good } \\
\text { descriptive about him. } \\
\text { 13) Teacher asks some students to write their } \\
\text { description on the whiteboard. While } \\
\text { composing the writing the teacher facilitates } \\
\text { the students and helps them. }\end{array}$ \\
\hline $\begin{array}{l}\text { 7. Compare their } \\
\text { descriptive text by } \\
\text { valuing the content of } \\
\text { the text }\end{array}$ & $\begin{array}{l}\text { 14) Teacher allows the students to exchange their } \\
\text { work and let them valuing the difference of the } \\
\text { content among their work. }\end{array}$ \\
\hline
\end{tabular}

Based on these main activities, there were the suitability and appropriateness of managing the detail activities. The activities which were set followed the stages of indicators. In fact, the teacher did not miss any single activity based on the lesson plan. Additionally, the teacher tried to deliver the activities within suitable learning strategy. Practically, the teacher introduce the concept of the topic by giving example and asked them to pick out one example based on their understanding and experience. Then, the teacher tried to emphasized their knowledge into concept and procedure and attitude of how to learn.

These evidences showed the teacher's ability that the teacher competently created meaningful and creative learning process. As a result, the teaching and learning process could be achieved comprehensively by the students because the teacher had managed the activities well based on the learning stages 
that the students needed to come with. Besides, the material development was also coherent to the learning stages and learning activities. It facilitated the students to compose a descriptive text as it was also stated as the goal of the learning based on basic competence.

Providing meaningful learning process, the teacher organized the activities well. The students were ordered to master the easiest thing and began to step higher. Regarding to this route of learning, the teacher manage the activities, as well as the material, systematically. Because of this systematicity of activity phases, what the students had gained connected them to decisions of the next phase (Shambaugh \& Magliaro, 2006).

Indeed, based on the implementation of the lesson plan, the teacher could create meaningful teaching and learning process. The teacher succeeded in implementing the lesson plan had been made. The teacher could assist the students with factual, conceptual, and procedural learning process. As a result the teacher could finish the activities with knowing that the students had achieved the competence.

\section{CONCLUSION AND SUGGESTION}

The teacher's ability in composing lesson plan was exceptional. The teacher had concerned much to the concept and procedure in developing lesson plan. It can be shown from the interconnectivity among all the components of lesson plan; they are basic competence, sub basic competence, indicator, learning objective, teaching and learning activities, method, learning strategy, media and sources, and assessment. Additionally, by having a brief knowledge of the 
curriculum, the teacher did not lose his attention to create systematic and coherent lesson plan.

Furthermore, since the lesson plan had been developed well, it indicated to meaningful teaching and learning activities. Through the lesson plan, the teacher could assist the students in achieving the competence. It seemed that the teaching and learning activities facilitate the students in doing such activity in which the teacher had settled in the indicators so that the students could follow the path of learning. From the opening, main, and closing activities, the teacher did comprehensively to point out the essence of each part of activity. Consequently, from the starting activity to the end, the activities were best applied by the teacher for the students so that the students could gain their competence.

Having analyzed the reputable teacher's developing lesson plan and its implementation in classroom activities, the researcher suggests for the other teachers that creating a good lesson plan is a worthy. The reputable teacher's lesson plan can be as an example of a good lesson plan which is applicable for the other teachers. However, they should adapt the lesson plan based on the curriculum used in the school. The lesson plan can make the teaching and learning activities meaningful. 


\section{REFERENCES}

Brown, H. D. (2004). Language Assessment: Principles and Classroom Practices. California: Longman.

Calvin, B. J., \& Chumba, N. E. (2011). Teacher's pedagogic Competence and Pupils' Academic Performance in English in Franchopone Schools. Educational Research for Policy and Practice, 2, 1094-1105.

Harmer, J. (2007). How to Teach English. Essex: Longman Pearson.

Hook, J. N., \& Evans, W. H. (1982). The Teaching of High School English. New York: John Wiley \& Sons, Inc.

Loughran, J. (2010). What Expert Teachers Do: Enhancing Professional Knowledge for Classroom Practice. Crows Nest: Allen \& Unwin.

Morrison, G. R., Ross, S. M., \& Kemp, J. E. (2007). Designing Effective Instruction (Fifth ed.). New Baskerville: John Wiley \& Sons, Inc.

Patel, M. F., \& Jain, P. M. (2008). English Language Teaching: Methods, Tools, \& Techniques. Jaipur: Sunrise Publishers \& Distibutors.

Pratt, D. D. (1989). Three Stages of Teacher Competence: A Develpmental Perspective. New Direction for Adult and Continuing Education, 1989(43), 78.

Richard, J. C. (2001). Curriculum Development in Language Teaching. Cambridge: Cambridge University Press.

Sanjaya, W. (2008). Perencanaan dan Desain Sistem Pembelajaran. Jakarta: Kencana Prenada Media Group.

Shambaugh, N., \& Magliaro, S. N. (2006). Instuctional Design: A systematic Approach for Reflective Practice. Boston: Pearson Education, Inc.

Shulman, L. S. (1986). Those who Understand: Knowledge Growth in Teaching. Educational Researcher, 15, 4-14.

Sujinah. (2011). Model Pengembangan Kurikulum \& Pembelajaran SiswaCI (Cerdas Istimewa). Surabaya: PMN.

Thosmas, R. M. (2003). Blending Qualitative and Quantitative Research Methods in THESES and DISSERTATIONS California: Corwin Press, Inc. 
Usman, M. U. (2004). Menjadi Guru Professional. Bandung: P.T. Remaja Rosdakarya.

Valentino, C. P. F. (2010). The ESOL Infused Lesson Plan (EILP). In J. A. Carmona (Ed.), Language Teaching and Learning in ESL Education: Current Issues, Collaborations, and Practice. Charlotte: Kona Publishing and Media Group.

Widdowson, H. G. (2002). Language Teaching: Defining the Subject. In H. T. Lomax \& G. Ferguson (Eds.), Language in Language Teacher in Education. Philadelphia: John Benjamins Publishing Company. 